\title{
A Cost-based Explanation of Gradual, Regional Internationalization of Multinationals on Social Networking Sites
}

\author{
Pogrebnyakov, Nicolai
}

Document Version

Accepted author manuscript

Published in:

M I R: Management International Review

DOI:

$10.1007 / \mathrm{s} 11575-016-0281-\mathrm{z}$

Publication date:

2017

License

Unspecified

Citation for published version (APA):

Pogrebnyakov, N. (2017). A Cost-based Explanation of Gradual, Regional Internationalization of Multinationals on Social Networking Sites. M I R: Management International Review, 57(1), 37-64.

https://doi.org/10.1007/s11575-016-0281-z

Link to publication in CBS Research Portal

\section{General rights}

Copyright and moral rights for the publications made accessible in the public portal are retained by the authors and/or other copyright owners and it is a condition of accessing publications that users recognise and abide by the legal requirements associated with these rights.

\section{Take down policy}

If you believe that this document breaches copyright please contact us (research.lib@cbs.dk) providing details, and we will remove access to the work immediately and investigate your claim.

Download date: 26. Apr. 2023
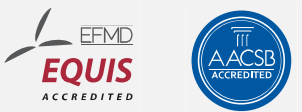


\section{A Cost-based Explanation of Gradual, Regional Internationalization of Multinationals on Social Networking Sites}

\section{Nicolai Pogrebnyakov}

Journal article (Accepted version)

CITE: A Cost-based Explanation of Gradual, Regional Internationalization of Multinationals on Social Networking Sites. / Pogrebnyakov, Nicolai. In: $M / R$ : Management International Review, Vol. 57, №. 1, 02.2017, p. 37-64.

The final publication is available at Springer via http://dx.doi.org/10.1007/s11575-016-0281-z

Uploaded to Research@CBS: July २017 


\title{
A Cost-Based Explanation of Gradual, Regional
}

\section{Internationalization of Multinationals on Social Networking}

\section{Sites}

\author{
Nicolai Pogrebnyakov \\ Copenhagen Business School, Frederiksberg 2000, Denmark
}

\begin{abstract}
This paper examines firm internationalization on social networking sites (SNS). It systematically examines costs faced by an internationalizing firm and how firms react to these costs according to "distance-dependent" (gradual and regional) and "distance-invariant" (born-global) explanations of internationalization. Data on 5827 country pages of 240 multinational firms on Facebook, the most popular SNS today, is used. Creating a foreign country-specific Facebook page is considered the SNS equivalent of opening a physical subsidiary in that country. The data show that multinationals exhibit internationalization behavior described by distance-dependent explanations, rather than the distance-invariant view, despite seemingly lower internationalization costs. Specifically, firms start internationalizing to institutionally closer countries, and gradually expand to more institutionally distant countries. They also tend to internationalize within their home region. The results point to the relevance of distancedependent explanations of internationalization even in a seemingly low-friction environment of SNS, and the importance of explicitly accounting for internationalization costs in studies of cross-border expansion.
\end{abstract}




\section{Keywords}

Multinational corporations; internationalization; regional strategy; global strategy; social networking sites; Facebook

\section{Introduction}

Entering new national markets traditionally has been seen as advantageous for firms, with benefits including access to new markets, resources and economies of scale (Ruigrok and Wagner 2003; Hitt et al. 2006). However, the specific process through which firms expand across borders has been extensively debated. The debate occurs between two broad views. What can be labeled the distance-dependent view of internationalization sees it as a gradual process, with firms expanding into less familiar countries as they gain experience (Johanson and Vahlne 1977). Further, most firms stay primarily within the boundaries of a single geographic region (Ghemawat 2003; Rugman and Brain 2003). By contrast, the more recent born-global view maintains that some firms internationalize quickly into many new and unfamiliar markets (Knight and Cavusgil 2004). If there is any common ground among the two views, it is that large multinational enterprises (MNCs) appear to follow a staged distance-dependent process, while the born-global approach is predominantly used by small and medium firms, particularly in some industries (Ruigrok and Wagner 2003).

A major enabler of the born-global strategy is information and communication technologies (ICTs) (Knight and Cavusgil 2004). Many studies of born-globals underscore the importance of ICT in quickly reaching out to new markets, lowering communication, operating and transaction costs (Zhang and Tansuhaj 2007). This allows even small firms to 
internationalize quickly and at low cost, as well as successfully maintain operations abroad (Axinn and Matthyssens 2002).

Of course, MNCs also invest heavily in ICTs. Depending on the industry, IT spending varies from $1 \%$ in construction to $6.7 \%$ in software as percentage of revenue (Hinchcliffe 2015). ICT investment continues to grow: e.g., in 2013 70\% of Fortune 500 companies had a Facebook presence, up by 4\% from 2012 (Barnes et al. 2013). ICTs are used throughout the whole value chain of an MNC, from research and new product development, to production or service delivery, to after-sales service, often in an integrated manner (Panetto and Molina 2008). Clearly, established MNCs also face higher internationalization costs compared to small born-globals. Examples of such costs include the need to coordinate activities among a diverse base of subsidiaries and the costs of adapting products to a wide range of local markets (Contractor 2007; Ruigrok and Wagner 2003). It can be expected that, as for small born-globals, ICTs would lower at least some internationalization costs for MNCs as well. This may facilitate further internationalization. And if MNCs are placed in an environment that by itself lowers at least some of the internationalization costs, even MNCs may start exhibiting internationalization behavior similar to that of born-globals. In that case, staged theories of internationalization may lose their relevance.

I test this argument by exploring MNC internationalization on social networking sites (SNS), an environment that may lower internationalization costs. SNS are web-based services that allow individuals and organizations to create profiles, establish connections with other users and view connections established by themselves and by others (Boyd and Ellison 2008; Lin and Lu 2011). Empirically, data was collected on Facebook, which is the most popular SNS today (Gelles and Isaac 2016). As in the physical world, MNCs can "enter" various countries by 
opening presence ("pages," or "accounts") for these countries. (The exact mechanism of how internationalization proceeds on SNS is reviewed below.) In such environment it can be expected that costs of coordinating activities across subsidiaries may be lowered because of, e.g., uniform, instantaneous communication (Dong-Hun 2010).

More specifically, this paper has two goals. First, it systematically reviews costs of internationalization derived from institutional theory, the transaction cost approach and the resource-based view. The paper then analyzes the possible impact of SNS on these costs, showing that there is no coherent perspective on whether internationalization costs on SNS are low or high. Second, departing from these inconsistencies, the paper aims to determine whether costs of internationalization on SNS are lower to the extent that MNCs do not follow a staged internationalization process but behave more like born-globals. If that is the case, as ICTs develop and lower internationalization costs further, we may expect the significance of distancedependent explanations of internationalization to diminish in the future. However, studies in other seemingly "frictionless" environments such as equity trading and information system adoption showed the importance of distance (Barrot et al. 2008) and the continuing relevance of distance-dependent internationalization models (Beugelsdijk and Frijns 2010). The second goal is, therefore, to determine the applicability of either distance-dependent or distance-invariant explanations of internationalization to a new domain where they have not been explored: SNS.

The results indicate that it is the distance-dependent logic, rather than the distanceinvariant born-global explanation, that explains MNC internationalization on SNS, however this effect diminishes with time.

Achieving these goals allows the paper make three contributions. First, the paper systematically investigates the impact of SNS on internationalization costs, an underexplored but 
increasingly important area as many companies integrate SNS into their business models.

Second, it determines the applicability of two explanations of internationalization in the SNS environment, which at first glance may reduce internationalization costs. It was found, however, that distance-dependent explanations are supported by the data. This result therefore extends internationalization theories into a new, previously underexplored domain: SNS. Third, the study explores broad patterns of the use of one (and currently the largest) SNS platform, Facebook, by MNCs from several industries.

\section{Literature review}

At a very general level, theories and frameworks of firm internationalization can be grouped into two major categories depending on importance they place on cross-country differences in firm internationalization. The first group of frameworks advocates distance-dependence. It includes, for the purposes of this paper, staged models such as the internationalization process model (Johanson and Vahlne 1977) and models based on similar logic (Petersen and Pedersen 1999). This group also includes various explanations of differences between countries, e.g., cultural distance (Yildiz 2014) or institutional distance (Kostova 1997). This group also includes the regional internationalization (Rugman and Brain 2003) and the semi-globalization (Ghemawat 2003) perspectives. The second, distance-invariant, group consists of various flavors of the bornglobal perspective (Knight and Cavusgil 1996; Oviatt and McDougall 2005). The born-global framework has been applied primarily to small and medium-sized enterprises (SMEs), to a large extent because newly formed SMEs may be subject to lower internationalization costs than established, large firms. 
A wide variety of studies have highlighted benefits and costs of internationalization for the firm (Ruigrok and Wagner 2003; Contractor 2007). The balance between the two has repeatedly been shown to be non-linear, typically with greater costs in the beginning (as the firm gains experience) and in the end (as it reaches the limit of its internationalization space) of its theoretical internationalization process (Ruigrok and Wagner 2003; Contractor 2007).

This paper focuses on specific internationalization costs and the ways in which these costs can be mitigated. This review will show that SNS may lower these costs for MNCs as well and thus the distance-invariant born-global logic may appear a viable explanation for MNE internationalization in the SNS space.

\section{Costs faced by an internationalizing firm}

According to distance-dependent explanations of internationalization, firms do not internationalize rapidly over space and time because of some constraints associated with the internationalization process (Hymer 1960/1976). At the organizational level, which is the focus of this paper, issues of firm internationalization are viewed variously through the lens of institutional theory (Contractor 2007), the transaction cost approach (Ruigrok and Wagner 2003) and the resource-based view (Cuervo-Cazurra et al. 2007), as noted by Buckley and Lessard (2005). Each of these theories emphasizes its own core set of constraints that a firm needs to overcome to establish presence in a specific foreign location. These constraints, or costs, need to be borne out by the internationalizing firm in the internationalization process. The following costs are frequently mentioned in the organization-level theories.

a) Learning and accumulation of internationalization experience. In the beginning of internationalization the firm does not possess knowledge of conducting business abroad (Dutta 
and Beamish 2013). With foreign expansion it accumulates such knowledge and enhances its organizational ability to extend its operations to multiple markets (Contractor 2007).

b) Internal coordination of cross-border activities. Increased spatial distance between firm units places additional burden on coordinating internal firm activities, such as operational and logistical coordination required to realize advantages of scale and scope (Hitt et al. 1997; Eden and Miller 2001). Strategy and incentives among the headquarters and subsidiaries also need to be reconciled, as do the costs of transaction governance across units (Lu and Beamish 2004).

c) Interactions with external actors. Entering multiple host countries requires attuning to relationships with external actors, such as governments and suppliers (Hitt et al. 1997; CuervoCazurra et al. 2007). Heterogeneous legal and cultural environments in different host countries increase the costs of managing these relationships with the number of countries entered by the firm grows ( $\mathrm{Lu}$ and Beamish 2004). Also included here are the costs of interacting with the firm's partners when the mode of entry is collaborative, rather than a wholly-owned subsidiary (Eden and Miller 2001).

d) Local adaptation of the product and business model. Cultural and normative idiosyncrasies of countries often require adaptation of the firm's products or services to the local context (Cavusgil and Zou 1994). Product design, attributes or functionality may need adaptation. Additionally, the method of promoting and provisioning the product (the business model), including distribution and pricing, may need to be adapted as well (Griffith 2010).

e) Legitimacy acquisition. A firm achieves legitimacy when it and its actions are seen as conforming to the norms and values in a particular country (Suchman 1995). Obtaining legitimacy in a market, either through firm's actions or shaped by environmental forces, is often 
critical to the success of the firm in that market (Bianchi and Ostale 2006; Suchman 1995).

However, achieving and maintaining legitimacy in a foreign environment is likely to impose significant costs on the firm (Fainshmidt et al. 2014).

On balance, internationalization is generally beneficial to firms, at least up to a certain extent (Ghemawat 2001; Contractor 2007; Lu and Beamish 2004). When costs of internationalization are substantial, firms must develop strategies to mitigate them in order to be able to internationalize. This situation is described by distance-dependent explanations of internationalization and is discussed in the next section. In circumstances where internationalization costs are seen as negligible, firms' internationalization behavior has been described by distance-invariant explanations, which are reviewed in the subsequent section.

\section{Distance-dependent explanations of internationalization}

Some combination of the internationalization costs reviewed in the previous section may preclude an internationalizing firm from expanding into any market at will, in turn suggesting a certain logic or path of internationalization (Chetty and Campbell-Hunt 2004). Such internationalization path is premised on some concept of "distance" between the home and the host countries of the MNC, or between host countries into which MNC has already entered and potential host countries. This "distance" can be conceptualized as geographic distance or distance in a more abstract sense referring to differences between countries on some measures (e.g. between countries' cultures or political institutions). Regardless of the specific conceptualization, these differences or distances between countries are seen as constraining firm internationalization. Let us look at explanations of firm internationalization suggesting that firms mitigate internationalization costs by constraining their internationalization in time and space. 
Gradual internationalization and institutional distance. One of the most popular gradual explanations of internationalization is the internationalization process model (Johanson and Vahlne 1977). It takes the view that internationalization is time-dependent and firms expand into more countries as they gain more experience in countries they already entered, while simultaneously becoming more committed to these markets. The choice of subsequent markets to enter is conditioned on the psychic distance between the home and the host countries, and as firms gain internationalization experience they can tolerate greater differences in psychic distance between markets. Psychic distance was described in the original model as the uncertainty of operating in a foreign environment stemming from the lack of information about the market (Johanson and Vahlne 1977). Later studies developed a more specific operationalization, defining it as, e.g., cultural distance based on Hofstede's dimensions (Yildiz 2014; Hofstede 1980).

Subsequent work focused on more precise formulations of psychic distance, with recent developments underscoring the role of institutional distance. It departs from the organizational strand of institutional theory and combines regulative, normative and cognitive-cultural components (Scott 2013). The regulative component describes formal constraints on behavior, exemplified by regulations and rules. (Another variety of institutional theory, the new institutional economics (North 1990), often describes institutions as primarily this regulative construct.). The normative component describes values and norms (e.g., in an organization or a society). It reflects patterns of behavior that are considered appropriate and expected. The cognitive-cultural component describes collective beliefs and views of social meaning and social reality (Scott 2013). At the same time, institutional components operate at multiple levels of analysis (Kostova 1997; Xu and Shenkar 2002). The organization should be attuned to the often 
conflicting pressures from the society, industry and increasingly individuals (this last pressure may manifest, e.g., through IT-enabled channels such as social networks). Of course, for an MNC these pressures are multiplied by the number of different national markets they have entered (Kostova and Roth 2002). However, acting on these components in ways that are considered appropriate is necessary for the organization to attain legitimacy (Suchman 1995; Bianchi and Ostale 2006).

Institutional distance between countries thus describes differences between countries along the three pillars. While the three pillars have been clearly distinguished theoretically, in practice researchers may combine some of them, particularly the normative and the cognitivecultural ones, or omit one of them altogether (Pogrebnyakov and Maitland 2011). Institutional distance has also to a large degree incorporated and superseded the popular liability of foreignness framework, which postulates that new entrants into a market are disadvantaged compared to similar local players due to their unfamiliarity with the local environment (Denk et al. 2012). Furthermore, this model places particular emphasis on learning and obtaining internationalization experience. The original model has seen learning as accumulation of foreign knowledge and sensing of market opportunities. Recent work has developed more nuanced understandings of learning as, e.g. the enhancement of firm-specific knowledge of how to establish and run its operations in foreign locations.

The internationalization process model suggests the following explanations of how MNCs mitigate individual internationalization costs. Because of its high emphasis on internationalization experience, the model sees learning as placing temporal limits on internationalization. A firm progressively enters more (and more institutionally distant) countries as it accumulates internationalization experience. Subsidiaries function, among other, as "local 
sensors," acquiring local knowledge and disseminating it to the rest of the MNC (Gnyawali et al. 2009). This also helps mitigate the costs of adapting the firm's product or operations to local conditions and preferences. By expanding into more institutionally close, and therefore more familiar, countries first, the firm reduces local adaptation costs because they are presumably less in more institutionally close countries. However, some authors have taken exception to this view, warning of a "psychic distance paradox" (O'Grady and Lane 1996) where firms overestimate the familiarity of a foreign market and thus underestimate local adaptation costs.

Gradual international expansion also allows the firm to build foundations for legitimacy in one country before moving on to the next (Denk et al. 2012). From this base the firm can further strengthen its legitimacy in the local market, as well as transfer the knowledge of building legitimacy to other units, thereby enhancing its internationalization experience (Peng 2012).

Regional internationalization. The internationalization process model does not place any geographical boundaries on MNC expansion. Given enough time, an MNC can theoretically accumulate enough experience so as to expand into even the most psychically or institutionally distant countries and become a global MNC. However, recently both empirical findings (Rugman and Verbeke 2004; Li 2005; Asmussen 2009) and theoretical arguments (Ghemawat 2005; Rugman and Oh 2013) have highlighted the prevalence and justifiability of MNC strategies that are based on geographic regions, rather than the entire globe. A typical definition of what constitutes a region is from Rugman and Verbeke (2004), who identify three regions, North America (including Mexico), EU and Asia Pacific, within which most MNC activity is concentrated.

A regional strategy might make sense for an MNC for several reasons. First, it can be seen as a complement to the institutional distance logic: institutionally close countries are more 
likely to be found within the home country region than outside of it (Ghemawat 2005; Rugman and Oh 2013; Asmussen 2009). Therefore such strategy may allow the firm to reduce internationalization costs in a way similar to what was described in the previous section. Second, a regional strategy represents a balance between advantages of operating across multiple markets (e.g., economies of scale and scope) while not being subjected to operational risks of operating far from the home country (Rugman and Brain 2003; Li 2005). This helps the MNC maintain acceptable costs of coordinating cross-border activities both internally within the firm and externally with the firm's supply chain and other external actors (Rugman and Verbeke 2004). Third, in recent years regional trade blocs have proliferated, which has been coupled with regionalization of FDI (Ghemawat 2011). It may be beneficial for an MNC to operate within the boundaries of such a regional trade bloc, where trade barriers might be lower, than to venture outside of it (Asmussen 2009). This facilitates local adaptation for the MNC in the host countries, both of the end product as well as from the organizational and cultural perspectives. Thus a regional strategy offers a viable way for an MNC to mitigate internationalization costs.

\section{Distance-invariant explanations of internationalization}

In contrast to distance-dependent explanations of internationalization discussed in the previous section, in some frameworks the constraints placed on internationalization by space or time is minimal. These views of internationalization have been variously labeled as born global, international entrepreneurial SMEs and international new ventures (Gabrielsson et al. 2008; Knight and Cavusgil 2004; Sharma and Blomstermo 2003). This paper will use "born-global" for consistency. Some of the most salient differences between born-globals and the distancedependent views of internationalization are that born-globals internationalize very soon after 
being created, the home market does not provide a large share of sales and their internationalization path often cannot be explained by a broadly defined "distance" logic (Chetty and Campbell-Hunt 2004). In this model, internationalization knowledge, which staged models postulate to be gradually accumulated by the firm, to a large extent already resides within the firm, e.g., through founder's experience (Weerawardena et al. 2007).

Researchers concur that the proliferation of born-globals to a large extent is due to developments in information technology and trade liberalization (Knight 2001). However, there has been considerable debate on specific circumstances that facilitate the emergence of bornglobals and whether this phenomenon is more characteristic of certain industries (e.g. hightechnology products) or home countries (e.g. small) (Moen 2002). Researchers have noted that in some cases a firm that appeared to be born global in fact may have undergone staged internationalization, but did so in a compressed timeframe, precluding the research methodology employed to discern it (Moen and Servais 2002). Other studies have reported that many bornglobals internationalize within their own region and thus conform to the regional expansion view of internationalization (Contractor 2007; Lee 2010).

However, the most salient aspect of the born-global view for this research is how these firms respond to costs faced by internationalizing firms. The need to build up internationalization experience is mitigated by significant knowledge that firm founders may have (Oviatt and McDougall 2005). This makes it possible to enter a greater number of foreign locations from the beginning compared to the distance-dependent view (Knight and Cavusgil 2004). The nature of the product offered by the firm may be such that it has global market potential and requires little local adaptation (Gabrielsson et al. 2008). Another consequence of having such product is that building legitimacy in each foreign location may not be necessary, or at least can be significantly 
lowered. Furthermore, cross-border activities at various steps in the value chain, including R\&D, marketing, production (where applicable), sales and after-sales are greatly facilitated by information technology (Aggarwal et al. 2011).

Table 1: Costs of internationalization and the response to these costs according to distancedependent and distance-invariant frameworks of internationalization.

\begin{tabular}{|c|c|c|}
\hline $\begin{array}{c}\text { Cost/barrier to } \\
\text { internationalization }\end{array}$ & $\begin{array}{c}\text { Firm reaction to these barriers } \\
\text { according to } \underline{\text { distance-dependent views }} \\
\text { (institutional distance, regional } \\
\text { globalization) }\end{array}$ & $\begin{array}{c}\text { Firm reaction to these barriers } \\
\text { according to } \underline{\text { distance-invariant views }} \\
\text { (born global) }\end{array}$ \\
\hline $\begin{array}{l}\text { a) Internationalization } \\
\text { experience and knowledge } \\
\text { of how to establish } \\
\text { operations in foreign } \\
\text { locations }\end{array}$ & $\begin{array}{l}\text { Places temporal limits on } \\
\text { internationalization: entry into more } \\
\text { countries occurs as experience } \\
\text { accumulates }\end{array}$ & $\begin{array}{l}\text { Significant internationalization } \\
\text { knowledge at firm creation (e.g. } \\
\text { provided by the founder), making it } \\
\text { possible to internationalize into more } \\
\text { locations from the beginning }\end{array}$ \\
\hline $\begin{array}{l}\text { b) Internal coordination of } \\
\text { cross-border activities }\end{array}$ & $\begin{array}{l}\text { Places spatial limits on } \\
\text { internationalization: regional strategies }\end{array}$ & $\begin{array}{l}\text { Greatly facilitated by information and } \\
\text { communication technologies }\end{array}$ \\
\hline $\begin{array}{l}\text { c) Interactions with external } \\
\text { actors }\end{array}$ & $\begin{array}{l}\text { Places spatial and temporal limits on } \\
\text { internationalization: accumulated } \\
\text { experience and regional strategies }\end{array}$ & $\begin{array}{l}\text { Not relevant, or facilitated by choice of } \\
\text { familiar markets or control-retaining } \\
\text { entry modes }\end{array}$ \\
\hline $\begin{array}{l}\text { d) Product and business } \\
\text { model adaptation }\end{array}$ & $\begin{array}{l}\text { Expansion to more familiar countries } \\
\text { first where adaptation costs are expected } \\
\text { to be lower }\end{array}$ & $\begin{array}{l}\text { May not be needed (e.g. due to the } \\
\text { nature of the product) }\end{array}$ \\
\hline e) Legitimacy acquisition & $\begin{array}{l}\text { Gradual expansion; building legitimacy } \\
\text { in one country before moving on to the } \\
\text { next }\end{array}$ & Not seen as required \\
\hline
\end{tabular}

The difference between distance-dependent and distance-invariant views on how firms mitigate or sidestep internationalization costs is shown in Table 1.

An assumption in born-global studies is that this internationalization logic applies primarily to small firms. A corollary, if often implicit, assumption is that large MNCs as a rule 
follow a staged internationalization process. This assumption, of course, helps explain a large proportion of differences between distance-dependent and distance-invariant views. For example, having top management experienced in internationalization in a small firm allows the firm to build an internationalization strategy and implement it faster than in a large multinational corporation, where top management may not be as experienced in internationalization (even though many companies increasingly hire top management with international experience) and where multiple internal and external stakeholders are often involved in implementing an internationalization decision. Similarly, it may be easier to coordinate cross-border activities in a small firm that does not face the challenges of incompatible and legacy IT systems, different organizational practices and multiple hierarchical levels scattered around its multiple locations.

At the same time, many of the costs faced by an internationalizing firm described above can be mitigated using technology. The following section focuses specifically on SNS and shows that in some respects IT, and SNS in particular, may help MNCs mitigate internationalization costs and even make them behave in certain respects more like born-globals.

\section{Social networking sites (SNS)}

SNS are defined here as a web-based service that allows individuals and organizations to create own profiles, establish connections with other users and view connections established by themselves and by others (Boyd and Ellison 2008; Lin and Lu 2011). SNS are popular among individual users because they afford their users a high degree of self-disclosure, or the ability to form an image of a person and disseminate it among the person's relationships (Kaplan and Haenlein 2010). Controlling one's image is typically an important desire of individuals in social interactions (Goffman 1959). SNS are also intrinsically enjoyable to use (Lin and Lu 2011), and 
this hedonic, or pleasure-oriented nature of these information systems is an important contributor to their continued use (Heijden 2004).

Firms can use these relationship-building and hedonic characteristics of SNS to engage with their customers. For example, SNS allow firms to build on users' relationships to distribute information through electronic word-of-mouth, seek opinion from users or establish new or strengthen existing relationships among users (Chu and Kim 2011; Piskorski 2011). To achieve that, SNS typically provide functionality that allows firms to establish a profile, create content and connect with individual users among others.

Examples of SNS popular today include Facebook, Google+, Twitter and LinkedIn (Duggan et al. 2015). Although there are some differences among these SNS, including types of underlying social networks they target (e.g. LinkedIn is aimed at establishing professional connections) and some technical aspects (e.g., posts on Twitter may not exceed 140 characters), models of firm presence and user engagement are similar across SNS (Rybalko and Seltzer 2010; Piskorski 2011; Men and Tsai 2012). With regards to firm presence, for example, Walmart, a US retailer, has dedicated accounts for its UK subsidiary on SNS Facebook, Twitter, Google+ and LinkedIn, while Danone, a French food producer, has accounts on these networks for its US subsidiary. Further, companies engage users on these networks through mechanisms such as "followers" (users who subscribe to messages the company periodically publishes on that network), "likes" (expressions of positive emotional attitude towards the company or messages it publishes) or "talking about" (mentions of the company in other users' posts).

Empirically this study is based on Facebook as the most popular SNS today (Gelles and Isaac 2016). Given the similarities among SNS in two aspects that are relevant for this study: models of firms presence and user engagement, as well as the fact that companies often replicate 
their social media strategies across several SNS (Hanna et al. 2011), results obtained here may be generalizable to other SNS, although establishing this would require further empirical testing.

\section{Internationalization costs in the SNS space}

\section{Internationalization on SNS}

There is general agreement among researchers and practitioners that ICT in general, and SNS in particular, lowers barriers to internationalization, even if it does not eliminate them completely. From MNC's organizational perspective, the low-latency and high-transparency communication helps alleviate costs imposed by geographical distance among its units (Sambharya et al. 2005; Yu et al. 2013). ICT also standardizes and sometimes helps formalize certain activities (typically upstream) at the organizational and supply chain levels, such as operations management and R\&D. All this facilitates coordination of cross-border activities. However, this requires significant ICT capability of the MNC, and indeed some authors have pointed out that ICT is a firm-specific asset that in itself may provide competitive advantage (Yu et al. 2013).

ICT also helps increase local responsiveness in downstream activities, such as marketing, where this is needed, e.g. by differentiating the product (Yu et al. 2013; Zou et al. 2010; Sambharya et al. 2005). This arguably facilitates local adaptation for the MNC. Greater ICT capability on the part of MNC may help overcome the liability of foreignness (Zou et al. 2010; Rhee 2008), thereby facilitating acquisition of legitimacy in foreign markets. With technological advances, as well as greater use of currently underutilized ICT capabilities by firms (Zou et al. 2010), these barriers can be expected to be lowered even further in the future.

This research is interested in SNS from a slightly different perspective than simply as a reducer of internationalization costs. It sees SNS as an "internationalization space," where firms 
may internationalize similarly to how they do in the physical world. Firms may create global only presence (e.g., a Facebook page); however, many MNCs choose to create country-specific presence, similar to how firms create subsidiaries in countries they enter. This presence on SNS can be used to support activities across the whole value chain, including product development, branding, sales and customer support (Culnan et al. 2010).

\section{Internationalization costs on SNS}

Being a subset of ICT, SNS can be expected to lower at least some internationalization costs. Literature on SNS and internationalization is somewhat scarce, however extant studies point out that internationalization costs are indeed lower on SNS, and not only in the familiar downstream activities such as marketing, but also in upstream ones such as R\&D (Culnan et al. 2010).

Consider how costs and barriers to internationalization reviewed above may specifically unfold on SNS. Knowledge how to establish operations in foreign locations might be a significant barrier before the first entry (i.e., before the firm opens its first digital presence). Indeed, many firms face high barriers before establishing their first SNS presence (Weinberg and Pehlivan 2011). After the first "entry" the MNC may establish routines (sometimes referred to as "social strategy") and disseminate it among its subunits as a "best practice," similar to other organizational practices (Mudambi and Swift 2011; Ciabuschi et al. 2012). Such dissemination may not depend on whether the social strategy originated in the headquarters or one of the subunits, so long as the MNC has appropriate channels of distribution of best practices among the subunits (Luo 2005). Having learned these SNS practices subunits may start implementing it, and the costs of implementing them can be expected to be much lower than the initial implementation. 
Coordination of internal cross-border activities may be eased if SNS presence is coordinated from a centralized location (e.g. from the MNC's headquarters). On the other hand, if MNC subsidiaries are responsible for their own SNS activities, such coordination may be conditioned upon other intraorganizational processes involved in coordination among MNC units, which may hamper internal coordination. External coordination (including interaction with individual customers) would be eased if the MNC has a social strategy in place.

Local adaptation understood as tailoring the MNC's products to local tastes and preferences may occur more easily on SNS. A prominent mechanism through which this may occur is interactions with and instantaneous feedback from local individuals. However, this may depend on successful organizational and cultural adaptation, and the MNC may face similar challenges in this respect on SNS as it may in the physical world.

Finally, legitimacy acquisition on SNS is as important to the MNC as to other organizations and, indeed, individuals (Kietzmann et al. 2011). It is likely to be easier, or at least faster, to gain, but legitimacy may also decrease fast due to sometimes occurring waves of quickly dispersing negative comments. For example, American clothing brand Kenneth Cole used mass demonstrations in Egypt to promote its clothing on SNS, a move that was heavily criticized (Sprung 2012). MNC's incentives in gaining legitimacy may be increased because obtaining such legitimacy may be a precondition for lowering other costs described above. For example, tailoring the MNC's products to the local market requires the involvement of individuals, which are more likely to get involved if they see the MNC as legitimate. Further, an increasing number of MNCs view legitimacy on SNS as not only the end goal in itself, but also as an important thread reinforcing a larger fabric of legitimacy, which includes legitimacy 
stemming from its business operations, relations with employees and communities, environmental footprint and so on.

These arguments are summarized in Table 2.

Table 2: Hypothesized costs of internationalization on SNS.

\begin{tabular}{|l|l|l|}
\hline \multicolumn{1}{|c|}{ Internationalization costs } & Why these costs may be low on SNS & \multicolumn{1}{c|}{ Why these costs may be high on SNS } \\
\hline $\begin{array}{l}\text { a) Internationalization } \\
\text { experience and knowledge of } \\
\text { how to establish operations in } \\
\text { foreign locations }\end{array}$ & $\begin{array}{l}\text { "Entries" after the first significantly } \\
\text { less costly }\end{array}$ & $\begin{array}{l}\text { Initial learning barrier (before the first } \\
\text { "entry") high }\end{array}$ \\
\hline $\begin{array}{l}\text { b) Internal coordination of } \\
\text { cross-border activities }\end{array}$ & $\begin{array}{l}\text { Coordination from a central location, or } \\
\text { successful dissemination as a "best } \\
\text { practice" }\end{array}$ & $\begin{array}{l}\text { When devolved to subsidiaries and costs of } \\
\text { other intraorganizational coordination } \\
\text { activities are high }\end{array}$ \\
\hline $\begin{array}{l}\text { c) Interactions with external } \\
\text { actors }\end{array}$ & $\begin{array}{l}\text { Reduced costs of communication, } \\
\text { particularly with individual customers }\end{array}$ & $\begin{array}{l}\text { Increased communication efforts due to } \\
\text { exposure to a large number of individuals }\end{array}$ \\
\hline d) Local adaptation & $\begin{array}{l}\text { Tailoring products to the local market } \\
\text { facilitated by interactions with local } \\
\text { individuals }\end{array}$ & $\begin{array}{l}\text { Possible challenges with organizational } \\
\text { and cultural adaptation }\end{array}$ \\
\hline e) Legitimacy acquisition & May be faster to gain & May be quickly reduced \\
\hline
\end{tabular}

\section{Research dilemmas}

This discussion above paints a mixed picture of possible costs of internationalization on SNS.

Theoretically, arguments in support of both distance-dependent (if internationalization costs are high) and distance-invariant (if costs are low) views of internationalization may be advanced. To choose between these competing explanations and address the original question of how firms internationalize on Facebook, I propose two dilemmas: 
Dilemma 1. Does MNC internationalization on Facebook follow a time-dependent, gradual path predicted by the internationalization process model, or do entries occur in many countries simultaneously in a manner characteristic of born-globals?

Dilemma 2. Is MNC internationalization on Facebook largely constrained by regional

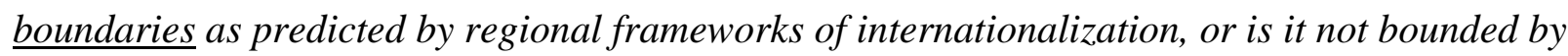
regional boundaries as is characteristic of born-globals?

These dilemmas are empirically tested using the methodology described in the next section.

\section{Methodology}

This paper performs theory building in the form of extending the domain of existing internationalization theories into the SNS space. Wacker (1998) notes that "theory-building research extends the domain of the theory," where the domain is "when and where the theory hold[s]". In a similar vein, Colquitt and Zapata-Phelan (2007) define theory building as "the degree to which an empirical article clarifies or supplements existing theory or introduces relationships and constructs that serve as the foundations for new theory". This article examines whether an existing theory, or rather two sets of theories (distance-dependent and distanceinvariant explanations of internationalization), holds in new settings (internationalization on SNS). Therefore it extends the domain of a theory as per Wacker's (1998) definition and clarifies and supplements existing theory using empirical evidence, satisfying theory building definition of Colquitt and Zapata-Phelan (2007). Further, the goal of this study is to "search for regularities and test in order to predict" (Gioia and Pitre 1990), thereby fitting their "functionalist paradigm", and it followed the nine theory building steps provided in that paper. 
Given this conceptual frame, the following sections describe sources of the data and the procedures of analyzing them.

\section{Data}

The dataset used in this study includes data on international Facebook pages of MNCs collected specifically for this study, as well as data from public sources.

Data for the dependent variable, MNC “entry” into a country on Facebook, run from November 2008 to September 2013, with monthly sampling. Facebook introduced the pages feature in November 2007 (Puddlegum 2007), and a one-year period was to ensure that this feature starts being adopted by firms en masse and discount the impact of early adopters, which may have features that differentiate them from the rest of adopters (Swanson 1994). I collected them using a list of 100 largest companies in 14 consumer-facing industries. I chose consumerfacing industries because they are more likely to use SNS, and do so for purposes of international entry as discussed above. The list of companies, their sales amounts and home countries was obtained from Dow Jones's Factiva service (http://global.factiva.com), and for each company a list of brands it operates under was obtained from Reuters (http://www.reuters.com/sectors). A list of 107 host countries based on whether more than 5\% of population of a country used Facebook in September 2013 was created. Then for each company and host country I checked the existence of a Facebook page for that country, along with the creation date of that page if it existed. A company was retained in the dataset if it had pages for five or more countries, which for the purposes of applying internationalization theories had a meaning analogous to subsidiaries. This approach is in line with internationalization in the physical world: the presence of subsidiaries is the most common way of defining an MNC (Aggarwal et al. 2011), although 
there is no commonly accepted number of subsidiaries that would qualify a firm as an MNC. For example, Minbaeva (2007) used two subsidiaries, Nohria and Ghoshal (1994) used five and James and Hill (1994) used seven. Five subsidiaries were chosen as the middle ground between these different approaches. This resulted in 240 companies with 5827 country pages, which were used for the analysis. Appendix B shows the distribution of all companies across industries.

Independent variables came from several sources. The regulatory component of institutional distance was calculated from the World Bank's Worldwide Governance Indicators (World Bank 2016), Government Effectiveness component, which reflects country regulations (Kirkpatrick et al. 2006). The cognitive-cultural component of institutional distance was calculated using data on languages and religious affiliation (Pogrebnyakov and Maitland 2011; De Groot et al. 2004). Other techniques, such as Hofstede's (1980) cultural dimensions, do not provide sufficient coverage for the countries in this dataset. To account for the regional strategy, I included a binary variable indicating whether the host country was in a different region as the company's home country. I defined regions as in Rugman and Brain (2003): North America, Europe and Asia.

I used several control variables. Data on Facebook use across countries came from Socialbakers.com. Sales data for companies for 2013 (or latest available) were obtained from Reuters. Data on population, GDP per capita and the proportion of mobile subscribers came from the World Bank. To compensate for skewed statistical distribution, I applied the logarithmic transformation to data on GDP per capita, population and firm sales. Where necessary, I converted yearly data into monthly with linear interpolation (Vdovichenko and Voronina 2006; Mason et al. 2000). A list of independent variables, their descriptions and descriptive statistics is shown in Appendix A. 


\section{Statistical procedures}

Since the dependent variable is binary, I used logistic regression to determine the entry of a firm into a host country $i$ in a time period $t$. The probability of such entry, $y_{i, t}$, is given by the logistic function, $\mathrm{P}\left(y_{i, t}=1 \mid \mathbf{x}_{i, t}\right)=\left(1+\exp \left(-\beta \mathbf{x}_{i, t}\right)\right)^{-1}$, where $\mathbf{x}_{i, t}$ is a matrix of values of independent variables and $\boldsymbol{\beta}$ is a vector of coefficients to be estimated.

The dataset includes time dependent observations for the same firm and host country (but different time periods). Therefore if $\mathrm{P}\left(y_{i, t}\right)$ is estimated directly in the form given above, standard errors may be incorrect, possibly being underestimated by $50 \%$ or more (Beck et al. 1998).

To mitigate this, I used cubic splines to model the effect of time to entry on the dependent variable, as suggested by Beck, Katz and Tucker (1998). Cubic splines are polynomials estimated on several intervals across the value range of the variable. The number of these intervals is specified by the researcher with the goal providing a good approximation of the effect of time on the dependent variable (I used seven intervals). In each interval, a polynomial of up to a third degree is fit to the data. Polynomials are joined at the boundaries of the intervals. To ensure a smooth function across all intervals, the fitting is done such that the splines along with their first and second derivatives agree at joint points. The estimated coefficients of the splines are then used to account for duration dependence in the model (Beck et al. 1998).

How would estimating this model indicate which alternative presented in the research dilemmas is supported? Table 3 shows the expected statistical significance and signs of coefficients for the independent variables that would support the distance-dependent and the distance-independent explanations of internationalization. 
Table 3: Expected statistical significance and signs of coefficients for the distance-dependent and distance-independent explanations of internationalization on Facebook.

\begin{tabular}{|c|c|c|c|}
\hline & Variable & $\begin{array}{c}\text { The distance-dependent explanation } \\
\text { would be supported if the coefficient } \\
\text { is... }\end{array}$ & $\begin{array}{c}\text { The distance-independent } \\
\text { explanation would be supported if the } \\
\text { coefficient is... }\end{array}$ \\
\hline \multirow[t]{4}{*}{ Dilemma 1} & $\begin{array}{l}\text { Regulative } \\
\text { institutional distance }\end{array}$ & Significant and negative & Not significant \\
\hline & $\begin{array}{l}\text { Change of } \\
\text { Regulative over } \\
\text { time }\end{array}$ & Significant and positive ${ }^{a}$ & Not significant \\
\hline & $\begin{array}{l}\text { Cognitive-cultural } \\
\text { institutional distance }\end{array}$ & Significant and negative & Not significant \\
\hline & $\begin{array}{l}\text { Change of } \\
\text { Cognitive-cultural } \\
\text { over time }\end{array}$ & Significant and positive ${ }^{a}$ & Not significant \\
\hline \multirow[t]{2}{*}{ Dilemma 2} & $\begin{array}{l}\text { Expansion into other } \\
\text { regions }\end{array}$ & Significant and negative & $\begin{array}{l}\text { Significant and positive, or not } \\
\text { significant }\end{array}$ \\
\hline & $\begin{array}{l}\text { Change of } \\
\text { Expansion over time }\end{array}$ & Significant and positive ${ }^{a}$ & $\begin{array}{l}\text { If Expansion is significant and } \\
\text { positive: significant and negative }{ }^{\text {a }} \\
\text { If Expansion is not significant: not } \\
\text { significant }\end{array}$ \\
\hline
\end{tabular}

${ }^{\mathrm{a}}$ Note: this would suggest that the importance of the respective component diminishes with time.

\section{Results}

\section{Pre-estimation tests}

I checked for possible multicollinearity in the data by calculating variance inflation factors (VIFs) (Powell and Rhee forthcoming; O'Brien 2007). VIF values are shown in Table 4. Different authors cite different criteria of VIF cutoff values that are suggestive of multicollinearity, with common recommendations of 4 (O'Brien 2007) or 10 (O'Brien 2007; Xu 
et al. 2004). As seen from Table 4, none of the variables has VIFs close to these cutoff values, and therefore I proceed with the assumption of no multicollinearity.

Table 4: Variance inflation factors (VIFs) of variables.

\begin{tabular}{|l|l|}
\hline \multicolumn{1}{|c|}{ Variable } & $\begin{array}{c}\text { Variance } \\
\text { inflation } \\
\text { factor }\end{array}$ \\
\hline Percentage of Facebook users & 1.73 \\
\hline GDP per capita & 2.74 \\
\hline Regulative institutional distance & 2.55 \\
\hline Population & 1.21 \\
\hline Firm sales & 1.05 \\
\hline Cognitive-cultural institutional distance & 1.06 \\
\hline Firm internationalization experience & 1.26 \\
\hline Home and host countries are in different regions & 1.06 \\
\hline
\end{tabular}

\section{Modeling results}

The results of model estimation are shown in Table 5. Clustered standard errors are shown to account for the fact that there are multiple observations for each firm and thus there are firmspecific clusters in the data.

Measures of model quality indicate a good fit. Nagelkerke's pseudo- $R^{2}$ is 0.28 , which compares well to studies of other complex international business phenomena (Lu 2002; Benito et al. 2003). The overall goodness-of-fit chi-square statistic is $112,194.1$ and is not significant $(p \approx$ 1), indicating good fit. The model is significantly better than the null model with only an intercept term: the residual deviance is 40,751 on 234,431 degrees of freedom, and is significant compared to the null deviance of 54,566 on 234,444 degrees of freedom $(p<0.001)$. 
Table 5: Results of the estimation of the effect of independent variables on the existence of an MNC Facebook page for a specific country.

\begin{tabular}{|l|l|l|}
\hline \multicolumn{1}{|c|}{ Variable } & \multicolumn{1}{|c|}{ Estimate } & \multicolumn{1}{|c|}{ Std. Error } \\
\hline (Intercept) & $-6.43^{* * *}$ & 0.43 \\
\hline Regulative institutional distance & $-0.58^{* * *}$ & $<0.01$ \\
\hline Cognitive-cultural institutional distance & $-1.37 * * *$ & 0.30 \\
\hline Regulative institutional distance $\times$ Time & $0.01^{* * *}$ & $<0.01$ \\
\hline Cognitive-cultural institutional distance $\times$ Time & $0.03^{* * *}$ & 0.01 \\
\hline Home and host countries are in different regions & $-0.34^{*}$ & 0.16 \\
\hline Home and host countries are in different regions $\times$ Time & 0.01 & $<0.01$ \\
\hline Firm sales & $<-0.01$ & 0.01 \\
\hline Firm internationalization experience & $0.0242^{* * * *}$ & $<0.01$ \\
\hline Firm internationalization experience ${ }^{2}$ & $<-0.01 * * *$ & $<0.01$ \\
\hline Percentage of Facebook users & $1.28^{* * * *}$ & 0.17 \\
\hline GDP per capita & -0.04 & 0.02 \\
\hline Population & $0.09 * * *$ & 0.01 \\
\hline Spline & $64.68^{* * * *}$ & 4.10 \\
\hline$* * * p<0.001, * * p<0.01, * p<0.05$ & & \\
\hline
\end{tabular}

Most individual coefficients are statistically significant at 0.05 level. Coefficients of both the regulative and the cognitive-cultural components of the institutional distance are statistically significant and have negative signs, indicating that the probability of entry is greater between countries with smaller distances. Furthermore, this effect decreases with time as indicated by the positive and significant coefficients of interaction terms between institutional distance and time. The coefficient of the binary variable describing whether the home and host countries are in different regions is significant and negative, suggesting that the probability of entry is greater between countries in the same region. No significant change of this effect over time has been 
detected, as suggested by the non-significant coefficient of the interaction between that binary variable and time.

Coefficients for most control variables are significant and have intuitive signs. Firm internationalization experience has a positive sign, indicating that entry is facilitated by previous entries, but that effect diminishes as the firm gains more experience, as suggested by the negative sign of the squared experience term. Greater number of Facebook users in a country facilitates entry, as does larger population. Firm sales and country GDP per capita were not found to have statistically significant effects.

The results overwhelmingly support distance-dependent explanations of internationalization. Dilemma 1, which weighed a time-dependent, staged internationalization path versus distance-invariant internationalization, was resolved in favor of staged internationalization. As indicated in Table 4, this is supported by significant and negative coefficients of institutional distance variables, and significant and positive coefficients of interaction terms of distance with time.

Dilemma 2 juxtaposed region-bounded internationalization and internationalization not constrained by regional boundaries. It was resolved in favor of region-bounded internationalization, given the significant and negative sign at the variable registering expansion into other regions.

\section{Discussion}

The general consensus appears to be that ICTs facilitate internationalization and decrease the importance of geographic distance (Sambharya et al. 2005). However, the results of this research point to the continuing relevance of geographical distance and cross-country differences for 
MNC internationalization, even in the seemingly frictionless realm of SNS, specifically

Facebook. This section analyzes the results in light of the two dilemmas put forward before and discusses broader implications for internationalization frameworks.

\section{Gradual internationalization: mitigating internationalization costs through temporal constraints}

With regard to dilemma 1 , the results suggest that firms follow a time-dependent, staged path when internationalizing on Facebook. Furthermore, internationalization can be explained by the institutional distance logic, where firms start internationalizing in countries that are institutionally close to their home country and progressively "enter" countries that are more institutionally dissimilar.

On SNS this process does not necessarily correspond, time-wise, to MNC internationalization in the physical world, and is likely disjoint from it. A firm entering a particular country in the physical world could not create a Facebook page prior to November 2007, when Facebook introduced pages (Puddlegum 2007). However, using the general premise of staged MNC internationalization, firms appear to have essentially replicated their general patterns of internationalization from the physical world on Facebook. Further, here internationalization was observed very shortly after the appearance of the very possibility of internationalization on Facebook.

More specifically, the effect of both regulative and cognitive-cultural components of institutional distance is significant and negative. A firm is more likely to have Facebook presence for a particular host country if regulations in that country are more similar to the firm's home country. Similarly, a firm is more likely to have Facebook presence in a country whose 
cultural characteristics resemble its home country. This lends support to the distance-dependent explanation of internationalization based on institutional distance. Furthermore, the effect of both regulative and cognitive-cultural components of distance diminishes with time.

These findings are in agreement with studies of internationalization in the physical world showing that firms progressively enter countries with greater institutional distance from their home country (Denk et al. 2012; Johanson and Vahlne 1977). However, the result that firms follow a staged internationalization process on Facebook, with institutional distance exerting significant influence on the choice of countries to "enter," is rather surprising, because SNS may lower some internationalization costs as discussed in the literature review. At the same time, these results lend support to studies in other seemingly "frictionless" environments where internationalization is temporally and spatially bounded (Beugelsdijk and Frijns 2010).

Therefore this result is particularly interesting, and suggests that firms may, consciously or not, imitate their internationalization behavior in the physical world on SNS. This can be explained from at least two angles. First, this result can be viewed through the lens of the effect of SNS on the structure of internationalization costs. The costs of internationalization on SNS, while on surface being lowered, may in fact have a pronounced effect on internationalization. Alternatively SNS may lower some costs, but the effect of the remaining costs is still significant. In particular, SNS may lower the costs of gaining internationalization knowledge, legitimacy acquisition and, when internationalization practices are centrally controlled or effectively disseminated, the coordination of cross-border activities. By contrast, the costs of local adaptation can be expected to be significant. Also, coordination of cross-border activities may not be eased much if internationalization is carried out in a poorly coordinated, distributed manner. 
Regulative distance may influence internationalization costs on SNS as follows. There are few differences in Facebook policies across countries. Therefore the significant effect of regulative distance may be an artifact from the physical world. Firms may transfer regulative differences between countries that do exist in the physical world into the SNS realm, where there are few differences, and allow these differences to affect decision-making in their internationalization. In other words, this effect may be due to perceptions of regulative differences among countries on SNS, rather than any existing differences. Whether this effect is acknowledged by firms or is an unintended spillover from the physical world might be a topic of further research.

Cultural distance, unlike regulative one, may directly influence some costs of internationalization on SNS. As in the physical world, there are cultural differences among countries on SNS (Kim et al. 2011). These differences may particularly affect the costs of local adaptation and legitimacy acquisition. Organizational adaptation may be hindered by the fact that interactions on SNS need to be done in a local language, even when languages are nominally the same (consider US and UK). More importantly, these interactions need to be tailored to the local context. Organizational strategy in a particular country also plays a role, and differences in firm strategies among countries have been well documented (Bartlett and Ghoshal 1986). Even internal organizational factors need to be carefully attuned to. Seemingly minor aspects such as product naming may differ among countries. Other cross-country differences within the same MNC may include different products, logos or packaging, distribution and after-sales channels, marketing campaigns etc. Many of these differences are due to country-specific cultural factors, and they should be reflected in SNS interactions. Added to that are a plethora of country-specific 
factors related to SNS use, such as interaction styles and attitudes to deception (Kim et al. 2011; Lewis and George 2008).

Legitimacy acquisition (as well as loss) may also vary by country and depend on cultural factors (Bianchi and Ostale 2006). Information may disseminate very fast on SNS, but the speed with which it does varies by country (Dow et al. 2013). Since information may be positive or negative for the MNC, legitimacy may be faster to build on SNS than in the physical world, but by the same token it may be quicker to reduce. Therefore cultural aspects may have an important effect on the cost of legitimacy building, which helps explain the significant effect of this factor in internationalization.

Another explanation of that result may be found in relationships between MNC units, or between the headquarters and subsidiaries. As with many other decisions and actions within MNC, internationalization on SNS may be performed centrally (e.g. from the headquarters or from another unit tasked with this), or by individual subsidiaries. It is easy to see how each of these configurations represents a tradeoff between organizational effectiveness and efficiency. Centralized operation may implement decisions across multiple presences on SNS quicker, and possibly with fewer resources, thus having the benefit of efficiency. However, a centralized operation may not be very responsive to, or even aware of, country-specific factors discussed above. Therefore it may lack in effectiveness. SNS operations run by individual subsidiaries, of course, would have a reverse of this tradeoff.

The significant effect of institutional distance may be due to indirect costs caused by this tradeoff between effectiveness and efficiency. When SNS operations are decentralized, the MNC may want to transfer best SNS practices among its subsidiaries. However, decentralization may result in greater communication latency or friction from transferring internationalization 
knowledge between the HQ and subsidiaries in regulatory and culturally distant subsidiaries. Acknowledging this, the MNC that aims at running a decentralized SNS operation may wish to start implementing this operation in culturally closer subsidiaries to mitigate this friction.

Conversely, a centralized SNS operation may suffer from a lack of effectiveness because staff at the centralized unit may not be very responsive to local conditions in various locations. To address this, the MNC may first "enter" countries on SNS that are more culturally close to its home country. After the organization's SNS management unit has gained some familiarity with SNS environments that are to some extent different than their home environment, internationalization can proceed to more culturally distant environments. This behavior is therefore similar to MNC actions in response to different cultural environments in the physical world.

\section{Regional strategies: mitigating costs through spatial constraints}

The results that correspond to dilemma 2 are less surprising, but still interesting because they lend further support to studies of internationalization in the physical world. To recall, the results suggest that firms on Facebook internationalize largely within their home region. This supports both empirical findings and theoretical arguments regarding internationalization in the physical world that MNCs tend to internationalize within their home region (Rugman and Verbeke 2004; Ghemawat 2005). Regional-based expansion on SNS may simply mirror such expansion in the physical world. Such expansion would allow firms to mitigate some of the internationalization costs, such as local adaptation and legitimacy acquisition, as countries in the same region often have similar cultural landscapes. At the same time countries in the same region often have tighter trade ties, translating into greater opportunities for the MNC to offer their products. Thus a 
regional strategy would allow MNCs to expand their SNS presence and gain internationalization experience in that domain. MNCs would thus reap benefits of internationalization while keeping its costs manageable.

However, this result also carries an interesting caveat. SNS theoretically allow MNCs to increase awareness of their products even in locations where they do not have physical operations (Dow et al. 2013). The assumption here may be that increasing this awareness may lead to increased involvement in the physical world, or lead directly to sales through the online channel, if the product allows this. At the same time, recall that costs of foreign "entries" on SNS after the first one are typically low, unlike entries in the physical world. Therefore, on the surface, MNCs would have the incentive to expand their presence to the entire SNS "world" (i.e., countries with sufficiently high Facebook adoption rates). However, the results indicate that firms still follow a region-based strategy. This suggests that MNCs, consciously or not, may be replicating their physical world internationalization path not only temporally (as predicted by institutional distance) but also spatially (the regional strategy).

\section{Conclusion}

This paper examined costs of internationalization, the configuration of these costs on SNS and whether that configuration of internationalization costs changes patterns of internationalization for firms on SNS compared to the physical world. It examined internationalization of MNCs on the largest SNS, Facebook, contrasting gradual, regional (distance-dependent) and born-global (distance-invariant) explanations of internationalization. Based on an analysis of 5827 country pages of $240 \mathrm{MNCs}$, support has been found for the distance-dependent explanation: firms start internationalizing in countries that are institutionally close to their home countries before 
gradually expanding into more institutionally diverse countries. MNCs also tend to internationalize within their home region.

The paper's theoretical contribution is thus twofold. First, it combined internationalization costs identified in the institutional theory, the transaction cost approach and the resource-based view into one overarching framework (see Table 1). Although there is general understanding in the international business literature that these costs exist and may be more or less pronounced for different companies in different circumstances, to my knowledge no crosstheory compilation of such costs has been made. The benefit of this approach is that it offers a common language to systematically explore and compare different explanations of internationalization. In this study it was used to compare distance-dependent and distanceinvariant explanations of internationalization in the physical world as well as internationalization on SNS. Other studies could deploy this framework in other domains to investigate the underlying logic of internationalization, e.g., in specific industries or of companies of certain size (such as SMEs).

The second theoretical contribution is in extending internationalization frameworks to SNS, a domain relatively unexplored by international business theorists but of rapidly growing importance to companies. This yielded a rather unexpected result that internationalization on SNS is characterized by distance dependence, rather than born-global behavior. That may appear counterintuitive, as ICT, and SNS in particular, are seen as decreasing costs to internationalization. However, the discussion of the findings demonstrated the continuing relevance of internationalization frameworks even in the domain that at first glance has the potential to allow relatively unconstrained internationalization for the MNC. At the same time, it showed the importance of explicitly accounting for internationalization costs and acknowledging 
how these costs may be altered in different internationalization domains or affected by external factors.

The study has practical implications. Managers responsible for SNS strategies at MNCs can use internationalization costs on SNS summarized in Table 2 as a basis for formulating and communicating a coherent SNS strategy among MNC subsidiaries. For instance, with regards to internationalization experience, managers can see both the potential cost in investing in internationalization on SNS (high initial learning barrier), as well as the possible payoff once that learning barrier is overcome (subsequent entries less costly). These considerations can also be used in intra-firm communication to motivate employees to engage in a training program that would increase their SNS competencies. Additionally, managers can use the findings to evaluate and possibly reassess the approach through which SNS presence (in particular, Facebook pages) for the MNC's subsidiaries are opened, and to compare the approach used by their firm with other firms. In other words, MNCs can ask themselves two questions: "How does our SNS internationalization strategy compare to strategies of other companies?" and "Does this strategy benefit us?". The results suggest that many MNCs gradually open presence in countries that are increasingly more different from MNC's home country, whether through a conscious decision to delegate SNS activities to subsidiaries, resulting from organizational processes that led to internationalization in the physical world, or from ad hoc developments. Such gradual approach can be beneficial in that the MNC may distribute its efforts in tailoring its SNS presence over time, however potential downsides are that some markets may not be covered by the MNC's SNS efforts, or that the MNC would not achieve a coherent SNS strategy across its host countries. This assessment may lead to a discussion of organizational processes used by the MNC to communicate its SNS strategy to subsidiaries. 
This study has its limitations. It was conducted using data only from Facebook, and while it is the largest SNS today (Gelles and Isaac 2016), considering other SNS such as Twitter, Google+ or LinkedIn would help triangulate the results and empirically test their generalizability across SNS. Further, this study considered only the existence of a company's Facebook page for a country, and not how actively maintained it was. Additionally, aiming to capture general patterns of internationalization on SNS, this study did not probe into headquarter-subsidiary relations and organizational practices that support SNS strategies.

Future studies in this area may investigate patterns of Facebook use at MNCs (e.g., mirroring the degree of commitment to the market reasoning in the internationalization process model), or focus on qualitative explanations of patterns of internationalization on SNS observed here, for example through interviews or observations at selected companies. Other internationalization models, such as gravity-based models, can also be used as theoretical basis for investigating internationalization behavior on SNS. 


\section{Appendix A. Independent variables included in the analysis}

\begin{tabular}{|c|c|c|c|}
\hline Variable & Description & Mean & $\begin{array}{l}\text { Standard } \\
\text { deviation }\end{array}$ \\
\hline $\begin{array}{l}\text { Percentage of Facebook } \\
\text { users }\end{array}$ & $\begin{array}{l}\text { Percentage of Facebook users in the host country } \\
\text { (monthly) }\end{array}$ & 0.284 & 0.167 \\
\hline GDP per capita & GDP per capita in the host country*, US dollars & $20,030.78$ & $19,510.33$ \\
\hline $\begin{array}{l}\text { Regulative institutional } \\
\text { distance }\end{array}$ & $\begin{array}{l}\text { Differences in regulatory quality between the home } \\
\text { and the host country, ranging from } 0 \text { (perfect } \\
\text { similarity) to } 5 \text { (perfect difference) }\end{array}$ & 3.268 & 0.911 \\
\hline Population & Host country population* & $75,774,632$ & $185,464,609$ \\
\hline Firm sales & Firm sales*, US dollars & $54,599,865,229$ & $62,723,895,325$ \\
\hline $\begin{array}{l}\text { Cognitive-cultural } \\
\text { institutional distance }\end{array}$ & $\begin{array}{l}\text { Cognitive-cultural distance between the home and } \\
\text { the host countries, ranging from } 0 \text { (perfect similarity) } \\
\text { to } 1.5 \text { (perfect difference) }\end{array}$ & 1.322 & 0.252 \\
\hline $\begin{array}{l}\text { Firm } \\
\text { internationalization } \\
\text { experience }\end{array}$ & $\begin{array}{l}\text { For each time period this variable shows the number } \\
\text { of country Facebook pages the firm has created up to } \\
\text { that period }\end{array}$ & 32.632 & 28.590 \\
\hline $\begin{array}{l}\text { Home and host } \\
\text { countries are in } \\
\text { different regions }\end{array}$ & $\begin{array}{l}\text { Whether the home and host countries are in different } \\
\text { geographic regions, binary variable }\end{array}$ & 0.799 & 0.400 \\
\hline
\end{tabular}

*Logarithmic transformation was applied to these variables. 


\section{Appendix B. Industries included in the research and the number of companies}

from these industries

\begin{tabular}{|l|l|}
\hline \multicolumn{1}{|c|}{ Industry } & $\begin{array}{l}\text { Number of } \\
\text { companies }\end{array}$ \\
\hline Automobiles & 44 \\
\hline Computers and Electronics & 43 \\
\hline Food and Beverages & 35 \\
\hline Personal Care Products and Appliances & 25 \\
\hline Consumer Products & 14 \\
\hline Dolls, Toys and Games & 13 \\
\hline Sports Goods & 13 \\
\hline Clothing & 12 \\
\hline Restaurants and Cafes & 9 \\
\hline Media & 8 \\
\hline Footwear & 8 \\
\hline Clothing Stores & 8 \\
\hline Telecommunications & 8 \\
\hline
\end{tabular}




\section{References}

Aggarwal, R., Berrill, J., Hutson, E., \& Kearney, C. (2011). What is a multinational corporation? Classifying the degree of firm-level multinationality. International Business Review, 20(5), 557-577, doi:http://dx.doi.org/10.1016/j.ibusrev.2010.11.004.

Asmussen, C. G. (2009). Local, regional, or global? Quantifying MNE geographic scope. Journal of International Business Studies, 40(7), 1192-1205.

Axinn, C. N., \& Matthyssens, P. (2002). Viewpoint: Limits of internationalization theories in an unlimited world. International Marketing Review, 19(4/5), 436-449.

Barnes, N. G., Lescault, A. M., \& Wright, S. (2013). Fortune 500 are bullish on social media: big companies get excited about Google+, Instagram, Foursquare and Pinterest. Dartmouth, MA: University of Massachusetts Dartmouth.

Barrot, C., Rangaswamy, A., Albers, S., \& Shaikh, N. I. (2008). The role of spatial proximity in the adoption of a digital product. Available at SSRN: $\underline{\text { http://ssrn.com/abstract }=1092893}$.

Bartlett, C. A., \& Ghoshal, S. (1986). Tap your subsidiaries for global reach. Harvard Business Review, 64(6), 87-94.

Beck, N., Katz, J. N., \& Tucker, R. (1998). Taking time seriously: time-series-cross-section analysis with a binary dependent variable. American Journal of Political Science, 42(4), 1260-1288.

Benito, G. R. G., Grøgaard, B., \& Narula, R. (2003). Environmental influences on MNE subsidiary roles: economic integration and the Nordic countries. Journal of International Business Studies, 34(5), 443-456.

Beugelsdijk, S., \& Frijns, B. (2010). A cultural explanation of the foreign bias in international asset allocation. Journal of Banking \& Finance, 34(9), 2121-2131. 
Bianchi, C. C., \& Ostale, E. (2006). Lessons learned from unsuccessful internationalization attempts: examples of multinational retailers in Chile. Journal of Business Research, $59(1), 140-147$.

Boyd, D. M., \& Ellison, N. B. (2008). Social Network Sites: Definition, History, and Scholarship. Journal of Computer-Mediated Communication, 13, 210-230.

Buckley, P. J., \& Lessard, D. R. (2005). Regaining the edge for international business research. Journal of International Business Studies, 36(6), 595-599.

Cavusgil, S. T., \& Zou, S. (1994). Marketing strategy-performance relationship: An investigation of the empirical link in export market ventures. Journal of Marketing, 58(1), 1-21.

Chetty, S., \& Campbell-Hunt, C. (2004). A strategic approach to internationalization: a traditional versus a "born-global" approach. Journal of International Marketing, 12(1), $57-81$.

Chu, S.-C., \& Kim, Y. (2011). Determinants of consumer engagement in electronic word-ofmouth (eWOM) in social networking sites. International Journal of Advertising, 30(1), 47-75, doi:http://dx.doi.org/10.2501/ija-30-1-047-075.

Ciabuschi, F., Dellestrand, H., \& Holm, U. (2012). The role of headquarters in the contemporary MNC. Journal of International Management, 18(3), 213-223, doi:http://dx.doi.org/10.1016/j.intman.2012.06.004.

Colquitt, J. A., \& Zapata-Phelan, C. P. (2007). Trends in theory building and theory testing: A five-decade study of the Academy of Management Journal. Academy of Management Journal, 50(6), 1281-1303.

Contractor, F. J. (2007). The evolutionary or multi-stage theory of internationalization and its relationship to the regionalization of firms. In A. M. Rugman (Ed.), Research in Global 
Strategic Management: Regional Aspects of Multinationality and Performance (Vol. 13, pp. 11-29). Oxford, UK: JAI Press.

Cuervo-Cazurra, A., Maloney, M. M., \& Manrakhan, S. (2007). Causes of the difficulties in internationalization. Journal of International Business Studies, 38(5), 709-725.

Culnan, M. J., McHugh, P. J., \& Zubillaga, J. I. (2010). How large US companies can use Twitter and other social media to gain business value. MIS Quarterly Executive, 9(4), 243-259.

De Groot, H. L. F., Linders, G.-J., Rietveld, P., \& Subramanian, U. (2004). The institutional determinants of bilateral trade patterns. Kyklos, 57(1), 103-124.

Denk, N., Kaufmann, L., \& Roesch, J.-F. (2012). Liabilities of foreignness revisited: a review of contemporary studies and recommendations for future research. Journal of International Management, 18(4), 322-334.

Dong-Hun, L. (2010). Growing Popularity of Social Media and Business Strategy. SERI Quarterly, 3(4), 112-117.

Dow, P. A., Adamic, L. A., \& Friggeri, A. The anatomy of large Facebook cascades. In Proceedings of the 7th International AAAI Conference on Weblogs and Social Media, Boston, MA, 2013.

Duggan, M., Ellison, N. B., Lampe, C., Lenhart, A., \& Madden, M. (2015). Social Media Update 2014. Washington, DC: Pew Research Center.

Dutta, D. K., \& Beamish, P. W. (2013). Expatriate Managers, Product Relatedness, and IJV Performance: A Resource and Knowledge-based Perspective. Journal of International Management, 19(2), 152-162, doi:http://dx.doi.org/10.1016/j.intman.2012.11.002. 
Eden, L., \& Miller, S. Opening the black box: multinationals and the costs of doing business abroad. In Academy of Management Proceedings, Washington, DC, 2001 (Vol. 2001, pp. C1-C6): Academy of Management.

Fainshmidt, S., White, G. O., \& Cangioni, C. (2014). Legal Distance, Cognitive Distance, and Conflict Resolution in International Business Intellectual Property Disputes. Journal of International Management, 20(2), 188-200, doi:http://dx.doi.org/10.1016/j.intman.2013.03.008.

Gabrielsson, M., Kirpalani, V. H., Dimitratos, P., Solberg, C. A., \& Zucchella, A. (2008). Born globals: propositions to help advance the theory. International Business Review, 17(4), $385-401$.

Gelles, D., \& Isaac, M. (2016). Can both Uber and Lyft stay competitive? https://www.bostonglobe.com/business/2016/01/08/lyft-and-uber-road-wide-enough-fortwo/2KecoXXw1kCQpNpXUSeZ8H/story.html. Accessed January 20, 2016.

Ghemawat, P. (2001). Distance still matters: the hard reality of global expansion. Harvard Business Review, 79(8), 137-147.

Ghemawat, P. (2003). Semiglobalization and international business strategy. Journal of International Business Studies, 34(2), 138-152.

Ghemawat, P. (2005). Regional strategies for global leadership. Harvard Business Review, 83(12), 98-108.

Ghemawat, P. (2011). World 3.0: Global Prosperity and How to Achieve It. Boston, MA: Harvard Business Press.

Gioia, D. A., \& Pitre, E. (1990). Multiparadigm perspectives on theory building. Academy of Management Review, 15(4), 584-602. 
Gnyawali, D. R., Singal, M., \& Mu, S. (2009). Knowledge ties among subsidiaries in MNCs: a multi-level conceptual model. Journal of International Management, 15(4), 387-400.

Goffman, E. (1959). The Presentation of Self in Everyday Life. New York, NY: Overlook Press.

Griffith, D. A. (2010). Understanding multi-level institutional convergence effects on international market segments and global marketing strategy. Journal of World Business, 45(1), 59-67.

Hanna, R., Rohm, A., \& Crittenden, V. L. (2011). We're all connected: The power of the social media ecosystem. Business Horizons, 54(3), 265-273, doi:http://dx.doi.org/10.1016/j.bushor.2011.01.007.

Heijden, H. v. d. (2004). User Acceptance of Hedonic Information Systems. MIS Quarterly, 28(4), 695-704, doi:http://dx.doi.org/10.2307/25148660.

Hinchcliffe, D. (2015). Is it IT's last chance to lead digital transformation? http://www.zdnet.com/article/is-it-its-last-chance-to-lead-digital-transformation/. Accessed February 3, 2016.

Hitt, M. A., Bierman, L., Uhlenbruck, K., \& Shimizu, K. (2006). The Importance of Resources in the Internationalization of Professional Service Firms: The Good, the Bad, and The Ugly. Academy of Management Journal, 49(6), 1137-1157, doi:http://dx.doi.org/10.5465/amj.2006.23478217.

Hitt, M. A., Hoskisson, R. E., \& Kim, H. (1997). International diversification: Effects on innovation and firm performance in product-diversified firms. Academy of Management Journal, 40(4), 767-798.

Hofstede, G. (1980). Culture's consequences: International differences in work-related values. Beverly Hills, CA: Sage Publications. 
Hymer, S. (1960/1976). The International Operations of National Firms: A Study of Direct Foreign Investment. Cambridge, MA: MIT Press.

James, W. L., \& Hill, J. S. (1994). MNC Product and Promotion Transfers. Journal of Global Marketing, 7(2), 51-74, doi:http://dx.doi.org/10.1300/J042v07n02_04.

Johanson, J., \& Vahlne, J.-E. (1977). The Internationalization Process of the Firm - A Model of Knowledge Development and Increasing Foreign Market Commitments. Journal of International Business Studies, 8(1), 23-32.

Kaplan, A. M., \& Haenlein, M. (2010). Users of the world, unite! The challenges and opportunities of Social Media. Business Horizons, 53(1), 59-68, doi:http://dx.doi.org/10.1016/j.bushor.2009.09.003.

Kietzmann, J. H., Hermkens, K., McCarthy, I. P., \& Silvestre, B. S. (2011). Social media? Get serious! Understanding the functional building blocks of social media. Business Horizons, 54(3), 241-251.

Kim, Y., Sohn, D., \& Choi, S. M. (2011). Cultural difference in motivations for using social network sites: a comparative study of American and Korean college students. Computers in Human Behavior, 27(1), 365-372.

Kirkpatrick, C., Parker, D., \& Zhang, Y.-F. (2006). Foreign direct investment in infrastructure in developing countries: does regulation make a difference? Transnational Corporations, 15(1), 143-171.

Knight, G. A. (2001). Entrepreneurship and strategy in the international SME. Journal of International Management, 7(3), 155-171.

Knight, G. A., \& Cavusgil, S. T. (1996). The born global firm: A challenge to traditional internationalization theory. Advances in International Marketing, 8, 11-26. 
Knight, G. A., \& Cavusgil, S. T. (2004). Innovation, organizational capabilities, and the bornglobal firm. Journal of International Business Studies, 35(2), 124-141.

Kostova, T. Country institutional profiles: concept and measurements. In Academy of Management Best Paper Proceedings, 1997 (pp. 180-184).

Kostova, T., \& Roth, K. (2002). Adoption of an organizational practice by subsidiaries of multinational corporations: institutional and relational effects. Academy of Management Journal, 45(1), 215-233.

Lee, I. H. (2010). The M curve: the performance of born-regional firms from Korea. Multinational Business Review, 18(4), 1-22.

Lewis, C. C., \& George, J. F. (2008). Cross-cultural deception in social networking sites and face-to-face communication. Computers in Human Behavior, 24(6), 2945-2964.

Li, L. (2005). Is regional strategy more effective than global strategy in the US service industries? Management International Review, 45(1), 37-57.

Lin, K.-Y., \& Lu, H.-P. (2011). Why people use social networking sites: An empirical study integrating network externalities and motivation theory. Computers in Human Behavior, 27(3), 1152-1161, doi:http://dx.doi.org/10.1016/j.chb.2010.12.009.

Lu, J. W. (2002). Intra- and inter-organizational imitative behavior: institutional influences on Japanese firms' entry mode choice. Journal of International Business Studies, 33(1), 1937.

Lu, J. W., \& Beamish, P. W. (2004). International diversification and firm performance: The Scurve hypothesis. Academy of Management Journal, 47(4), 598-609.

Luo, Y. (2005). Toward coopetition within a multinational enterprise: a perspective from foreign subsidiaries. Journal of World Business, 40(1), 71-90. 
Mason, J., Anari, A., \& Kolari, J. (2000). The Stock of Closed Bank Deposits, Duration of Credit Channel Effects, and the Persistence of the US Great Depression. LeBow College of Business, Drexel University.

Men, L. R., \& Tsai, W.-H. S. (2012). How companies cultivate relationships with publics on social network sites: Evidence from China and the United States. Public Relations Review, 38(5), 723-730, doi:http://dx.doi.org/10.1016/j.pubrev.2011.10.006.

Minbaeva, D. B. (2007). Knowledge transfer in multinational corporations. Management International Review, 47(4), 567-593, doi:http://dx.doi.org/10.1007/s11575-007-0030-4.

Moen, Ø. (2002). The born globals: a new generation of small European exporters. International Marketing Review, 19(2), 156-175.

Moen, Ø., \& Servais, P. (2002). Born global or gradual global? Examining the export behavior of small and medium-sized enterprises. Journal of International Marketing, 10(3), 49-72.

Mudambi, R., \& Swift, T. (2011). Leveraging knowledge and competencies across space: The next frontier in international business. Journal of International Management, 17(3), 186189, doi:http://dx.doi.org/10.1016/j.intman.2011.05.001.

Nohria, N., \& Ghoshal, S. (1994). Differentiated fit and shared values: Alternatives for managing headquarters-subsidiary relations. Strategic Management Journal, 15(6), 491-502.

North, D. C. (1990). Institutions, Institutional Change and Economic Performance. New York, NY: Cambridge University Press.

O'Grady, S., \& Lane, H. W. (1996). The psychic distance paradox. Journal of International Business Studies, 27(2), 309-333.

O’Brien, R. M. (2007). A caution regarding rules of thumb for variance inflation factors. Quality \& Quantity, 41(5), 673-690. 
Oviatt, B. M., \& McDougall, P. P. (2005). Defining International Entrepreneurship and Modeling the Speed of Internationalization. Entrepreneurship Theory and Practice, 29(5), 537-554, doi:http://dx.doi.org/10.1111/j.1540-6520.2005.00097.x.

Panetto, H., \& Molina, A. (2008). Enterprise integration and interoperability in manufacturing systems: Trends and issues. Computers in Industry, 59(7), 641-646.

Peng, G. Z. (2012). FDI legitimacy and MNC subsidiary control: From legitimation to competition. Journal of International Management, 18(2), 115-131, doi:http://dx.doi.org/10.1016/j.intman.2011.12.001.

Petersen, B., \& Pedersen, T. (1999). Fast and slow resource commitment to foreign markets: What causes the difference? Journal of International Management, 5(2), 73-91, doi:http://dx.doi.org/10.1016/S1075-4253(99)00007-1.

Piskorski, M. J. (2011). Social strategies that work. Harvard Business Review, 89(11), 116-122. Pogrebnyakov, N., \& Maitland, C. F. (2011). Institutional distance and the internationalization process: The case of mobile operators. Journal of International Management, 17(1), 6882, doi:http://dx.doi.org/10.1016/j.intman.2010.12.003.

Powell, K. S., \& Rhee, M. (forthcoming). Experience in Different Institutional Environments and Foreign Subsidiary Ownership Structure. Journal of Management.

Puddlegum (2007). Facebook introduces Facebook Pages: for artists and businesses. http://puddlegum.net/facebook-introduces-facebook-pages-for-artists-and-businesses/. Accessed January 20, 2016.

Rhee, J. H. (2008). International expansion strategies of Korean venture firms: entry mode choice and performance. Asian Business \& Management, 7(1), 95-114. 
Rugman, A. M., \& Brain, C. (2003). Multinational enterprises are regional, not global. Multinational Business Review, 11(1), 3-12.

Rugman, A. M., \& Oh, C. H. (2013). Why the home region matters: location and regional multinationals. British Journal of Management, 24(4), 463-479.

Rugman, A. M., \& Verbeke, A. (2004). A perspective on regional and global strategies of multinational enterprises. Journal of International Business Studies, 35(1), 3-18.

Ruigrok, W., \& Wagner, H. (2003). Internationalization and performance: An organizational learning perspective. Management International Review, 43(1), 63-83.

Rybalko, S., \& Seltzer, T. (2010). Dialogic communication in 140 characters or less: How Fortune 500 companies engage stakeholders using Twitter. Public Relations Review, 36(4), 336-341, doi:http://dx.doi.org/10.1016/j.pubrev.2010.08.004.

Sambharya, R. B., Kumaraswamy, A., \& Banerjee, S. (2005). Information technologies and the future of the multinational enterprise. Journal of International Management, 11(2), 143161.

Scott, W. R. (2013). Institutions and Organizations: Ideas, Interests and Identities (4th edition). Thousand Oaks, CA: Sage Publications Inc.

Sharma, D. D., \& Blomstermo, A. (2003). The internationalization process of born globals: a network view. International Business Review, 12(6), 739-753.

Sprung, R. (2012). 7 Rookie Social Media Mistakes From Big Brands. http://blog.hubspot.com/blog/tabid/6307/bid/31310/7-Rookie-Social-Media-MistakesFrom-Big-Brands.aspx. Accessed January 20, 2016.

Suchman, M. C. (1995). Managing legitimacy: strategic and institutional approaches. Academy of Management Review, 20(3), 571-610. 
Swanson, B. E. (1994). Information Systems Innovation Among Organizations. Management Science, 40(9), 1069-1092.

Vdovichenko, A. G., \& Voronina, V. G. (2006). Monetary policy rules and their application in Russia. Research in International Business and Finance, 20(2), 145-162.

Wacker, J. G. (1998). A definition of theory: research guidelines for different theory-building research methods in operations management. Journal of Operations Management, 16(4), 361-385, doi:http://dx.doi.org/10.1016/S0272-6963(98)00019-9.

Weerawardena, J., Mort, G. S., Liesch, P. W., \& Knight, G. (2007). Conceptualizing accelerated internationalization in the born global firm: a dynamic capabilities perspective. Journal of World Business, 42(3), 294-306.

Weinberg, B. D., \& Pehlivan, E. (2011). Social spending: managing the social media mix. Business Horizons, 54(3), 275-282.

World Bank (2016). Worldwide Governance Indicators. http://data.worldbank.org/datacatalog/worldwide-governance-indicators. Accessed January 20, 2016.

Xu, D., Pan, Y., \& Beamish, P. W. (2004). The effect of regulative and normative distances on MNE ownership and expatriate strategies. Management International Review, 44(3), 285307.

Xu, D., \& Shenkar, O. (2002). Institutional distance and the multinational enterprise. Academy of Management Review, 27(4), 608-618.

Yildiz, H. E. (2014). Not All Differences Are the Same: Dual Roles of Status and Cultural Distance in Sociocultural Integration in Cross-border M\&As. Journal of International Management, 20(1), 25-37, doi:http://dx.doi.org/10.1016/j.intman.2013.03.014. 
Yu, J., Han, K., \& Mithas, S. The role of information technology as a firm-specific advantage in internationalization of firms: theory and evidence. In 34th International Conference on Information Systems, Milan, Italy, 2013

Zhang, M., \& Tansuhaj, P. S. (2007). Organizational culture, information technology capability, and performance: the case of born global firms. Multinational Business Review, 15(3), 43-78.

Zou, H., Liu, X., \& Ghauri, P. (2010). Technology capability and the internationalization strategies of new ventures. Organizations and Markets in Emerging Economies, 1(1), 100-119. 